\title{
The effect of crude extracts of nine African chewing sticks on oral anaerobes
}

\author{
V. O. ROTIMI and H. A. MOSADOMI* \\ Departments of Microbiology and Parasitology and *Oral Pathology and Oral Biology, College of Medicine, \\ University of Lagos, P.M.B. 12003, Lagos, Nigeria
}

\begin{abstract}
Summary. Chewing sticks are widely used in Nigeria for dental and oral hygiene. Invitro susceptibility tests were done with crude extracts from nine popular sticks on four species of Bacteroides. Serindeia warneckei chewing stick had the greatest and most consistent inhibitory effect on the four species; extracts from bark and pulp were bactericidal at concentrations of $\leq 1 \%$. Extracts of other sticks, when inhibitory, were only so at higher concentrations-in the range $2-30 \%$. All the black-pigmented oral anaerobes were very susceptible to eight of the nine chewing-stick extracts but nonpigmented anaerobes showed variable susceptibilities.
\end{abstract}

\section{Introduction}

Dental plaque formation and gingivitis are associated with the early stages of development of periodontal disease (Löe et al., 1965; Syed and Loesche, 1978). There are numerous reports of studies on the microflora of the gingival crevice, dental plaque and chronic destructive periodontal disease. Most stress the importance of anaerobes in the aetiology of periodontal disease (Gibbons et al., 1963; Loesche et al., 1972; Kelstrup and Theilade, 1974; Slots, 1977; Duerden, 1980; Rotimi and Mosadomi, 1983). Clinical studies by Hine (1950) showed that the acquisition and maintenance of this microflora are associated with the accumulation of debris, leading to inflammation of the gingiva and subsequent infections. Others have corroborated this observation and shown that when bacterial deposits are removed the gingival inflammation subsides (Ramfjord and Kiester, 1954; Waerhaug, 1955).

The two methods employed by Nigerians to remove this debris are by tooth brush and paste, or by use of parts of various plants native to West Africa, referred to as "African Chewing Sticks". About $80-90 \%$ of the Nigerian population use chewing sticks, mainly because they are readily available, cheap and efficacious. A few use a combination of the two methods.

Medicinal properties associated with gum healing, analgesia, antisickling, haemostasis and astringence have been attributed to chewing sticks, as well as the possession of antimicrobial and plaque inhibiting effects (El-Said et al., 1971; Isaacs-Sodeye

Received 15 Aug. 1985; revised version accepted 18 Mar. 1986. et al., 1975; Wolinsky and Sote, 1983 and 1984; Rotimi et al., in press). Saliva-extracted "factors" obtained by chewing the end of the sticks produce an inhibitory effect on certain oral pathogens associated with the development of dental caries, gingivitis and other periodontal diseases (Enwonwu, 1974; Akpata and Akinrimisi, 1977; Rotimi et al., in press). In an earlier study on the anaerobic bacterial flora of the gingival crevice of adult Nigerians we reported that some African chewing sticks removed the black pigmented $\mathrm{Bac}$ teroides spp. of the normal flora (Rotimi and Mosadomi, 1983); other Bacteroides spp. appeared to be unaffected. This suggests the presence of antimicrobial substances specifically active against black-pigmented anaerobes. We report here the invitro susceptibility of some oral Bacteroides spp. to crude extracts of nine different chewing sticks. The different parts of each stick were also investigated to determine where the inhibitory substances may reside.

\section{Materials and methods}

\section{Bacterial strains}

Three reference strains of Bacteroides spp. and five strains isolated in our laboratory from clinical specimens were used as the test strains. The reference strains were $B$. oralis VPI 9958, B. melaninogenicus WPH 125 and $B$. gingivalis ATCC 33277; the local isolates were one $B$. oralis (gingival crevice), two B. melaninogenicus (gingival crevice) and two $B$. asaccharolyticus (gingival crevice).

\section{Culture media}

Kanamycin-blood agar (Blood Agar Base No. 2, 
Table I. Chewing sticks commonly used in Nigeria

\begin{tabular}{lll}
\hline \multicolumn{1}{c}{ Botanical names } & *Yoruba native name & $\begin{array}{l}\text { Plant part used } \\
\text { as chewing sticks }\end{array}$ \\
\hline Serindeia warneckei & Meyinro & Stem \\
Fagara zanthoxyloides & Orin Ata & Root \\
Distemonanthus benthamianus & Ayan & Root and Stem \\
Massularia accuminata & Pako Ijebu & Stem \\
Anogeissus leiocarpus & Pako dudu & Root \\
Vernonia amygdalina & Ewuro & Root and Stem \\
Bytyrospermum paradoxum & Igi Emi & Root \\
Terminalia glaucescens & Pako pupa & Root \\
Nauclea latifolia & Egbo Egbesi & Root \\
& & \\
\hline
\end{tabular}

* Yoruba is one of the three languages spoken in Nigeria.

Oxoid, with lysed human blood 5\% and kanamycin 75 $\mu \mathrm{g} / \mathrm{ml})$, blood agar, steamed Brain Heart Infusion Broth (BHI; Oxoid) to which menadione $1 \mu \mathrm{g} / \mathrm{ml}$ and L-cysteine hydrochloride $75 \mu \mathrm{g} / \mathrm{ml}$ were added, and steamed Robertson's cooked-meat broth, were used.

\section{Chewing sticks}

Nine chewing sticks commonly used in Nigeria are shown in table I, together with their native Yoruba (largely South-West Nigeria) names and the plant parts used as chewing sticks. All were bought in the open Nigerian market.

\section{Preparation of crude extracts}

Extracts were obtained from the bark, the pulp and the whole stick (i.e., the bark and pulp). The bark was peeled with a sharp knife and chopped into small pieces. The pulp and the whole stick were similarly chopped. Each part was weighed and stored separately in 10-g amounts in clean wide-mouthed 250-ml screw-capped bottles. Extracts were made by grinding the contents of a bottle in a pestle and mortar, adding $100 \mathrm{ml}$ of sterile deionised distilled water to the resultant fibres and allowing them to soak for $48 \mathrm{~h}$ in a cold room $\left(4^{\circ} \mathrm{C}\right)$, before decanting the fluid and centrifuging it at $2000 \mathrm{~g}$ for $10 \mathrm{~min}$. The supernate was passed through a $0.45 \mu \mathrm{m}$ membrane filter (Millipore Corp., Bedford, MA, USA). Extracts were stored in $5-\mathrm{ml}$ portions at $-20^{\circ} \mathrm{C}$ for no longer than 1 week.

\section{Tests for inhibitory action}

Bactericidal activity was determined for each set of extracts against reference and clinical isolates of the four Bacteroides spp. Each extract was diluted with prereduced BHI to give final concentrations of $80 \%, 50 \%$, $10 \%, 2 \%$ and $1 \%(\mathrm{v} / \mathrm{v})$. Each extract dilution was seeded with $0.1 \mathrm{ml}$ of a BIH-broth culture of each test strain diluted in sterile distilled water to give $c .10^{5} \mathrm{cfu} / \mathrm{ml}$. The bottles were incubated in anaerobic jars with a gas generating kit system (Oxoid) which generated approximately $\mathrm{H}_{2} 90 \%, \mathrm{CO}_{2} 10 \%$. The jars were controlled biologically by including in each jar a culture of Pseudomonas aeruginosa seeded on to a slant of Simmon's citrate agar. Incubation was at $37^{\circ} \mathrm{C}$ for $24 \mathrm{~h}$. B. fragilis NCTC 9343 was included in each experiment as a control. Bottles containing broth-free extracts and another containing broth only were seeded with the control strain and incubated along with each batch of tests. After incubation, the highest dilution that prevented visible growth of the test strains was taken as the inhibitory concentration. All tubes that showed no growth were subcultured on kanamycin-blood agar and plain blood agar and the bactericidal concentration was determined by the highest dilution at which there was no visible growth on solid media.

\section{Results}

Figs. 1-4 summarise the various effects of crude extracts of different components of nine chewing sticks on Bacteroides spp. found in the oral cavity. These effects were measured by relative inhibitory concentrations and relative bactericidal concentrations; both values were the same in most of the tests and, in the few instances when they were not, there was only a difference of one dilution. All the local isolates tested had the same susceptibility as their corresponding reference strains to each extract.

The relative bactericidal effects of the different extracts against $B$. gingivalis are shown in fig. 1 . Extracts of eight of the nine sticks were bactericidal at concentrations of $\leqslant 10 \%$. However, $F$. zanthoxyloides did not inhibit the growth of the organism after incubation for $24 \mathrm{~h}$. Essentially similar effects were produced by extracts of the same sticks on the other black-pigmented species, B. asaccharolyticus and B. melaninogenicus (figs. 2 and 3). However, the 
Plant species,

1. B. gingivalis

source of chewing stick

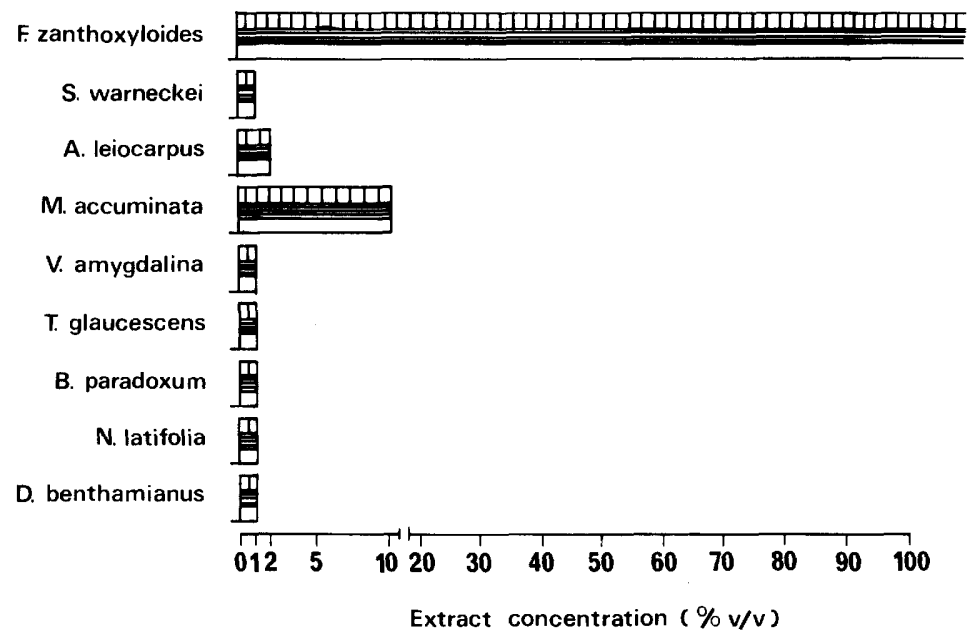

Plant species,

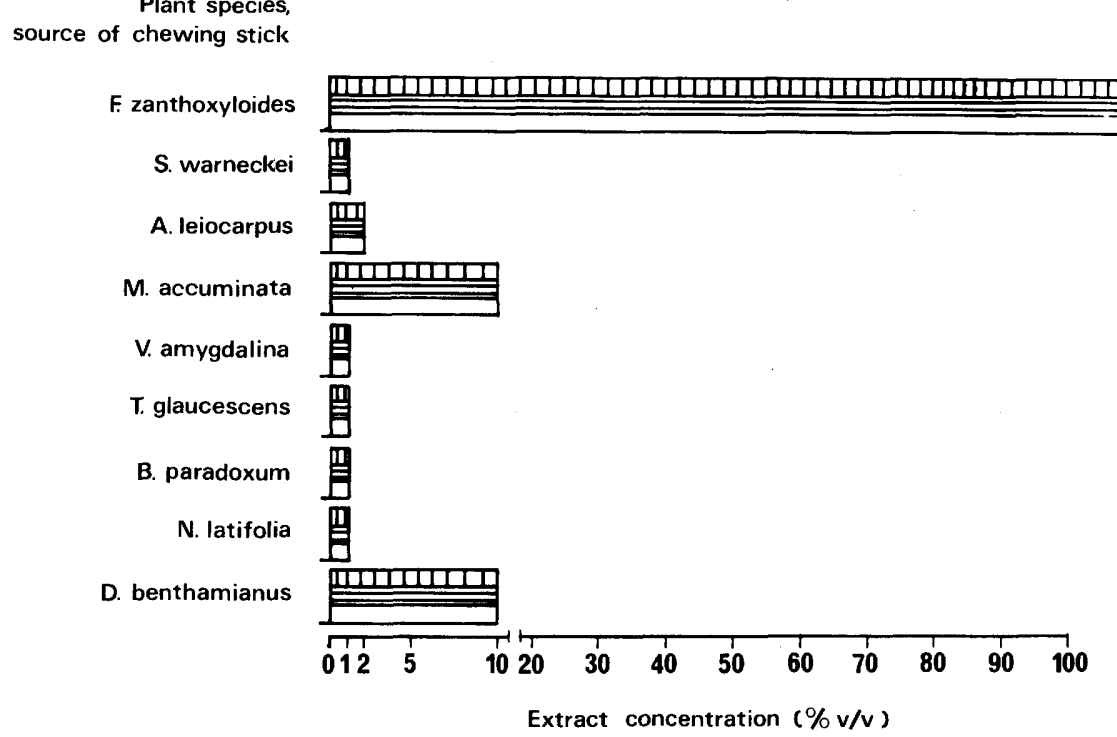

Figs. 1-4. Growth of oral Bacteroides strains in the presence of crude extracts of chewing sticks. Bars indicate growth up to the concentrations shown: 国 whole-stick extract; 四 bark extract; $\square$ pulp extract.

extracts of the whole stick and of the pulp of $A$. leiocarpus killed $B$. melaninogenicus at concentrations of $2 \%$, whereas the bark extract was bactericidal only at $10 \%$. Extracts of $F$. zanthoxyloides had no effect on the growth of either species.

Fig. 4 shows the effects of the chewing-stick extracts on another related but non-pigmented oral anaerobe, $B$. oralis. Extracts of $S$. warneckei and $T$. glaucescens and of the bark of $V$. amygdalina were capable of killing $B$. oralis at concentrations of $\leqslant 2 \%$. This species was also inhibited by $B$. paradoxum extract at a concentration of $50 \%$. Separate extracts of the bark and pulp of $A$. leiocarpus were not inhibitory whereas an extract of the whole stick killed the organism at a concentration of $2 \%$. $B$. oralis was completely resistant to extracts of F. zanthoxyloides, M. accuminata and only killed by $D$. benthamianus at a concentration of $80 \%$. 


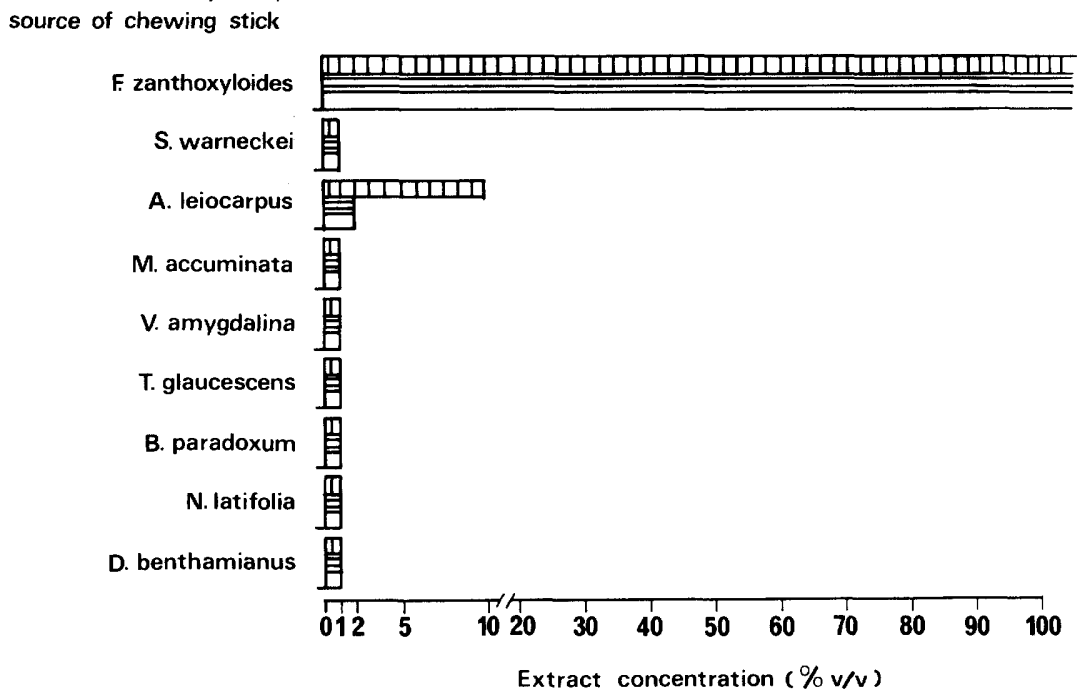

Plant species, source of chewing stick

F. zanthoxyloides

S. warneckei

A. leiocarpus

M. accuminata

V. amygdalina

T. glaucescens

B. paradoxum

N. latifolia

D. benthamianus

4. B. oralis
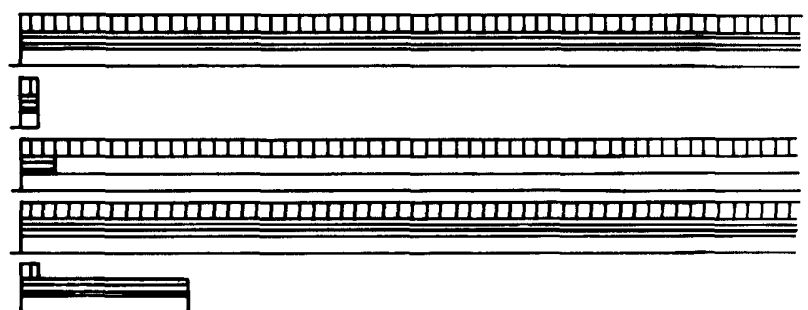

置
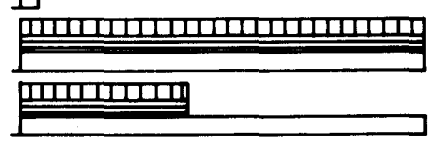

IIIIIIIIII

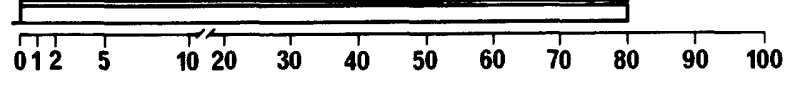

Extract concentration ( $\% v / v)$

\section{Discussion}

Nigerians use chewing sticks for their mechanical cleansing effect. The choice of stick depends largely on traditional preference rather than clinical effectiveness. The lower incidence of dental caries amongst users of chewing sticks (compared to nonusers) had been attributed to the superior mechanical cleansing action on the teeth (Enwonwu, 1974). A few earlier reports, however, demonstrated the antimicrobial properties of some of these sticks (ElSaid et al., 1971; Akpata and Akinrimisi, 1977). Our results confirm and extend these reports and show that $S$. warneckei has the most consistent inhibitory effect on all the Bacteroides spp. tested.

Extracts of $F$. zanthoxyloides were completely inactive against all the anaerobes tested. This observation was in agreement with that of Wolinsky and Sote (1983) who reported on the lack of effect of $F$. zanthoxyloides on the adherence and growth of 
the oral opportunist pathogen, Streptococcus mutans. Although this stick is used by Nigerians for dental hygiene its medicinal property such as the anti-sickling effect on red blood cells (Isaacs-Sodeye et al., 1975) has wider implications and has popularised its use, particularly among those with sickle-cell disease.

The high degree of sensitivity demonstrated by the black-pigmented anaerobes to all the sticks except $F$. zanthoxyloides is interesting. The patterns of inhibition of the three species were essentially identical; when there was any variation it was usually not more than one dilution. In contrast, $B$. oralis, a non-pigmented oral anaerobe, had a different sensitivity pattern; it was moderately sensitive to extracts of only three sticks. This may explain why black-pigmented strains are not commonly found in the gingival crevice of adult Nigerians who use chewing sticks for oral hygiene (Rotimi and Mosadomi, 1983) and may also partly explain the rarity of dental caries and gingivitis amongst the users of native chewing sticks for oral hygiene (Manley et al., 1975).

Until recently the active principle of these chewing sticks was not known. However, results of previous studies have shown that it is heat stable (Rotimi et al., in press) and soluble in methanol (Wolinsky and Sote, 1984). The recent report by Wolinsky and Sote (1984) has identified the active principles as tannin-like substances belonging to a large group of non-dialysible polyphenols of varying molecular weights. These tannins are said to be similar in quality but not necessarily in quantity in all chewing sticks.

\section{REFERENCES}

Akpata E S, Akinrimisi E O 1977 Antibacterial activity of extracts from some African chewing sticks. Oral Surgery, Oral Medicine, Oral Pathology 44:717-728.

Duerden B I 1980 The isolation and identification of Bacteroides spp. from the normal human gingival flora. Journal of Medical Microbiology 13:89-101.

El-Said F, Fadulu S O, Kuye J O, Sofowora E A 1971 Native cures in Nigeria. II. The antimicrobial properties of the buffered extracts of chewing sticks. Lloydia 34:172-174.

Enwonwu C O 1974 Socio-economic factors in dental caries prevalence and frequency in Nigerians: an epidemiological study. Caries Research 8:155-171.

Gibbons R J, Qureshi J V 1979 Inhibition of absorption of Streptococcus mutans strains to saliva-treated hydroxyapatite by galactose and certain amines. Infection and Immunity 26:1214-1217.

Gibbons R J, Socransky S S, Sawyer S, Kapsimalis B, MacDonald J B 1963 The microbiota of the gingival crevice area of man. II. The predominant cultivable organisms. Archives of Oral Biology 8:281-289.
Tannin-like substances are present in the bark and pulp of dicotyledonous plants and earlier reports have shown that they inhibit bacterial growth and are capable of protecting certain plants against bacterial infection (Uritani, 1971; Van Sumere et al., 1975). Our studies described here confirm the presence of material possessing antibacterial activity in extracts of such plants and we believe that the heat-stable polyphenol tannins reported earlier to be present in African chewing sticks are responsible for this activity. However, we believe that the quantities of the tannins in the bark and pulp of each species may vary.

The varying susceptibility of each anaerobic species may be a function of the available binding sites on the bacterial cell walls; these are probably bacterial surface proteins (Gibbons and Qureshi, 1979). Tannins have been shown to form irreversible complexes with proline-rich proteins (Hagerman and Butler, 1981) which would lead to inhibition of cell-wall-protein synthesis, a property that may explain the mode of action of these chewingstick extracts. We recommend, as an alternative to either the use of extracts as mouth rinses or the traditional use of the stick for oral hygiene, the incorporation of tannins and tannin-like substances extracted from some of the potent African chewing sticks, e.g., S. warneckei, into toothpaste. A double blind trial of conventional toothpaste versus that containing chewing-stick tannins should be done.

This study was supported by a College of Medicine, University of Lagos research grant which is gratefully acknowledged. Mr C. Tasie is also thanked for his secretarial assistance.

Hagerman A E, Butler L G 1981 The specificity of proanthocyanidin-protein interactions. Journal of Biological Chemistry 256:4494-4497.

Hine M K 1950 The use of a toothbrush in the treatment of periodontitis. Journal of American Dental Association 41:158-168.

Isaacs-Sodeye W A, Sofowora E A, Williams A O, Marquis V O, Adekunle A A, Anderson C O 1975 Extract of Fagara zanthoxyloides root in sickle cell anaemia: toxicology and preliminary clinical trials. Acta Haematologica 53:158-164.

Kelstrup J, Theilade E 1974 Microbes and periodontal disease. Journal of Clinical Periodontology 1:15-35.

Löe H, Theilade E, Jensen S B 1965 Experimental gingivitis in man. Journal of Periodontology 36:177-187.

Loesche W J, Hockett R N, Syed S A 1972 The predominant cultivable flora of tooth surface plaque removed from institutionalised subjects. Archives of Oral Biology 17:13111318.

Manley J L, Limongelli W A, Williams A C 1975 The chewing stick. Its uses and relationship to oral health. Journal of Preventive Dentistry 2(5):7-9.

Ramfjord S P, Kiester G 1954 The gingival sulcus and the 
periodontal pocket immediately following scaling of teeth. Journal of Periodontology 25:167-176.

Rotimi V O, Mosadomi H A 1983 Bacteroides spp. of the gingival crevice of adult Nigerians. Journal of Medical Microbiology 16: $\mathrm{x}$.

Rotimi V O, Mosadomi H A, Sogaolu O G The inhibitory action of aqueous extracts of some African chewing sticks on Streptococcus mitis: implication in dental caries. West African Medical Journal, in press.

Slots J 1977 The predominant cultivable microflora of advanced periodontitis. Scandinavian Journal of Dental Research 85:114-121.

Syed S A, Loesche W J 1978 Bacteriology of human experimental gingivitis: effect of plaque age. Infection and Immunity 21:821-829.

Uritani I 1971 Protein changes in diseased plants. Annual Review of Phytopathology 9:211-233.
Van Sumere C F, Albrecht J, Dedonder A, Depooter H 1975 Plant proteins and phenolics. In: Harborne J B, Van Sumere C F (eds) The chemistry and biochemistry of plant proteins. Academic Press, New York, pp 211-264.

Waerhaug J 1955 Microscopic demonstration of tissue reaction incident to removal of subgingival calculus. Journal of Periodontology 26:26-29.

Wolinsky L E, Sote E O 1983 Inhibiting effect of aqueous extracts of eight Nigerian chewing sticks on bacterial properties favouring plaque formation. Caries Research 17: 253-257.

Wolinsky L E, Sote E O 1984 The isolation of natural plaqueinhibiting substances from Nigerian chewing sticks. Caries Research 18:216-225. 